\title{
Strategies for Improving Phosphorus Use Efficiency in Lettuce Grown on Histosols'
}

\author{
Gustavo F. Kreutz, Jehangir H. Bhadha, Guodong D. Liu, Marcio F. R. Resende, Alan L. Wright, \\ D. Calvin Odero, and Germán V. Sandoya²
}

\section{Introduction}

Commonly referred to as "muck," the organic soils (Histosols) of the Everglades Agricultural Area (EAA) house nearly 11,000 acres of lettuce (Lactuca sativa L.) production every year (Sandoya and Lu 2020). The EAA's Histosols are continuously undergoing a process of soil subsidence (soil loss) via oxidation that affects soil $\mathrm{pH}$ and other properties. As Histosols become shallower over time, more minerals from the underlying limestone bedrock are incorporated into the soil surface, resulting in a higher $\mathrm{pH}$, lower availability of nutrients, and in turn, inadequate supply of phosphorus (P) for lettuce (Hochmuth et al. 2018; Bhadha et al. 2020). The absence of available $P$ in a lettuce production system can cause economic losses through marketable yield reduction. Symptoms of P deficiency in lettuce are manifested as chlorosis of the older leaves, irregular brown spots of dead tissue on outer foliage, delayed maturity, and reduced plant growth and yield (Figure 1).

Most P-derived fertilizers are produced from nonrenewable sources such as phosphate rock reserves, which are anticipated to be depleted in 70-140 years (Li et al. 2018). Strategies to optimize the efficiency of available $\mathrm{P}$ while maintaining high crop yields are imperative to reduce costs to growers and increase the lifespan of finite P reserves. These strategies must consider plant, soil, fertilizer, and agricultural management. Consequently, strategies to improve nutrient-use efficiency are unique to each production area.

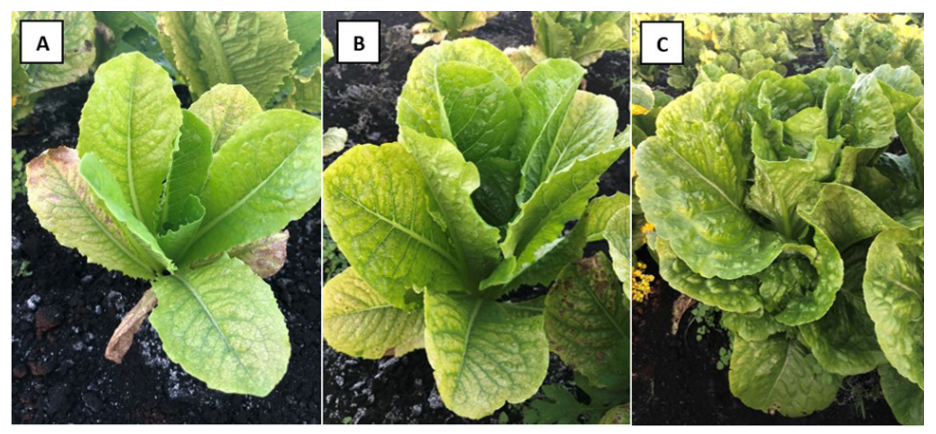

Figure 1. Different levels of phosphorus deficiency symptoms in lettuce, from severe (A), to moderate (B), and to absent (C). Credits: Gustavo F. Kreutz, UF/IFAS

This publication describes agricultural management practices that may contribute towards the long-term improvement of $\mathrm{P}$ availability and utilization in lettuce production areas in the EAA. These include adequate soil testing, establishment of a strong fertilization program, soil

1. This publication is HS1423, one of a series of the Horticultural Sciences Department, UF/IFAS Extension. Original publication date October 2021. Visit the EDIS website at https://edis.ifas.ufl.edu for the currently supported version of this publication.

2. Gustavo F. Kreutz, graduate student, Horticultural Sciences Department, UF/IFAS Everglades Research and Education Center; Jehangir H. Bhadha, assistant professor, Department of Soil and Water Sciences, UF/IFAS Everglades REC; Guodong D. Liu, associate professor, Horticultural Sciences Department; Marcio F. R. Resende, assistant professor, Horticultural Sciences Department; Alan L. Wright, associate professor, Department of Soil and Water Sciences, UF/IFAS Indian River REC; D. Calvin Odero, associate professor, Agronomy Department, UF/IFAS Everglades REC; and Germán V. Sandoya, assistant professor, Horticultural Sciences Department, UF/IFAS Everglades REC; UF/IFAS Extension, Gainesville, FL 32611.

All chemicals should be used in accordance with directions on the manufacturer's label.

The Institute of Food and Agricultural Sciences (IFAS) is an Equal Opportunity Institution authorized to provide research, educational information and other services

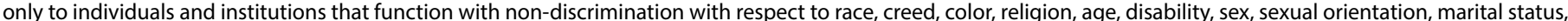
national origin, political opinions or affiliations. For more information on obtaining other UF/IFAS Extension publications, contact your county's UF/IFAS Extension office. U.S. Department of Agriculture, UF/IFAS Extension Service, University of Florida, IFAS, Florida A \& M University Cooperative Extension Program, and Boards of County Commissioners Cooperating. Tom Obreza, interim dean for UF/IFAS Extension. 
$\mathrm{pH}$ adjustment, proper water management, utilization of plant-growth-promoting microorganisms (PGPM), development and adoption of P-efficient lettuce cultivars by local breeding programs, and efficient weed management. The document is intended for lettuce growers, county Extension faculty, and crop consultants involved or interested in strategies to improve $\mathrm{P}$ availability in lettuce production in the EAA.

\section{Strategies for Improving Phosphorus Availability in Histosols}

Discussed below are seven strategies to improve the availability of soil P to the lettuce crop.

\section{SOIL CHEMICAL TESTING}

Preseason soil testing is imperative to ensure optimal fertilization. The correct collection of a soil sample is key to ensure proper fertilizer recommendations, and several important procedures must be followed:

- When sampling, avoid field edge areas (e.g., areas adjacent to roads and ditches).

- Conduct sampling after soil preparation but before bedding and planting.

- Take samples from the depth of the root zone of lettuce, which is approximately 6 inches.

- Collect representative samples. Approximately 30 soil cores from a 40 -acre area following a zigzag pattern will be adequate.

- Ensure sample homogenization. Mix soil cores thoroughly in a plastic bucket prior to packaging.

- Utilize a clean and clearly labeled plastic bag to place and transport the sample to the laboratory to prevent errors. A ziplock bag is a great packaging option for securing and maintaining the integrity of the sample.

Further information can be found in EDIS article SL225, Best Management Practices in the Everglades Agricultural Area: Soil Testing, at https://edis.ifas.ufl.edu/publication/ ss445 (Daroub et al. 2018).

\section{FERTILIZER MANAGEMENT}

Choosing the appropriate P fertilizer type, formulation, timing, placement, and method of application will maximize P uptake in lettuce. Inorganic sources are commonly used by vegetable growers in the EAA based on recommendations from the soil testing laboratory.

\section{PHOSPHORUS FERTILIZER RATE}

Phosphorus fertilizer rates for lettuce grown in the EAA are determined by the UF/IFAS Everglades Soil Testing Laboratory (ESTL) at the Everglades Research and Education Center. Although different fertilizer recommendations exist for iceberg and romaine, both types of lettuce usually respond similarly to different $\mathrm{P}$ rates (Mylavarapu et al. 2018). Interpretation of soil tests and recommendation of $\mathrm{P}$ fertilizer rates for iceberg and romaine lettuce produced in Histosols of the EAA are provided in Table 1. Detailed information about $\mathrm{P}$ recommendations for lettuce is provided in EDIS article SL486, Soil-Test-Based Phosphorus Recommendations for Commercial Agricultural Production in Florida, at https://edis.ifas.ufl.edu/publication/SS699 (Mylavarapu et al. 2021) and in EDIS article SP153, Fertilization Recommendations for Crisphead Lettuce Grown on Organic Soils in Florida, at https://edis.ifas.ufl.edu/ publication/WQ114 (Hochmuth et al. 2018).

\section{PHOSPHATE SOURCE}

Phosphate sources are available in many different formulations that vary based on primary $(\mathrm{N}, \mathrm{P}$, and $\mathrm{K})$ and secondary (Ca, $\mathrm{S}, \mathrm{Mg}$ ) macronutrients. All macroand micronutrient combinations must be taken into consideration when choosing the source of fertilizer to avoid suboptimal or excess applications. Failing to estimate proper concentrations of additional macronutrients may cause nutrient imbalances in the soil, harmful effects on the environment, and yield losses.

\section{TIMING OF APPLICATION}

Timing of fertilizer application directly influences fertilizer recovery by the lettuce crop. It is important that nutrient availability coincides with the periods when the crop needs nutrients the most (Hochmuth and Hanlon 2019). Lettuce is a relatively short-cycle crop (60-80 days); therefore, $P$ fertilization should be done at planting or during bed preparation (Figure 2).

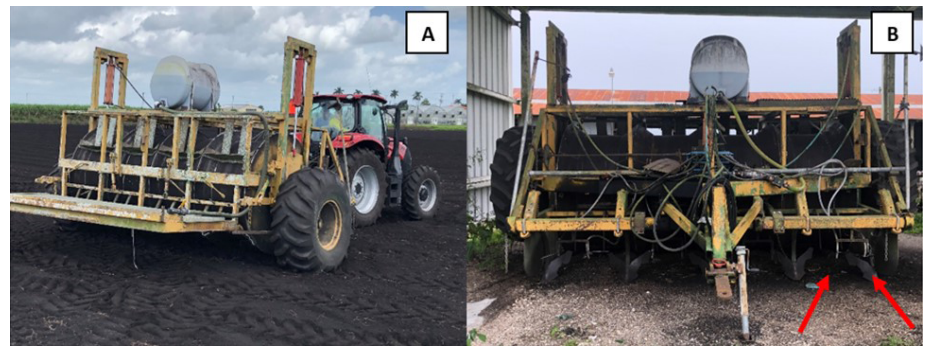

Figure 2. Machine for preparing raised beds for lettuce production on Histosols in the EAA (A, B). The fertilizer tank on the top of the machine is connected to nozzles that inject the liquid fertilizer while preparing the beds $(\mathrm{B})$.

Credits: Gustavo F. Kreutz, UF/IFAS 


\section{FERTILIZER PLACEMENT}

For lettuce grown on Histosols, band placement of $\mathrm{P}$ fertilizers was found to be advantageous compared to broadcasting (Guzman et al. 1987; Sanchez et al. 1990). Banded P fertilizers are applied near the root zones, usually 2 inches below the seed line in 3-to-5-inch-wide bands. This localized application reduces the contact area between soil and fertilizer, lowers binding of $\mathrm{P}$ in the soil, reduces interference of weeds, and decreases soil $\mathrm{pH}$ near the root zones when using acid-forming fertilizers such as monoammonium phosphate and diammonium phosphate (Santos et al. 2004; Wright et al. 2018). More information regarding the specific techniques for banding application of $\mathrm{P}$ in muck soils can be found in Bottcher et al. (1997).

\section{MANAGING SOIL pH}

Phosphorus is more available to plants when soil $\mathrm{pH}$ ranges between 5.5 and 6.5. Soil $\mathrm{pH}$ can be adjusted to enhance the solubility and uptake of $\mathrm{P}$ and other nutrients using certain amendments, such as sulfur (S). Once applied in the soil, $\mathrm{S}$ is converted into sulfate through oxidation, releasing hydrogen $\left(\mathrm{H}^{+}\right)$ions that reduce soil $\mathrm{pH}$. The major drawback of $S$ application is the additional cost associated with this practice. About $4,000 \mathrm{lb} \mathrm{S}$ per acre are required to reduce one unit of soil pH (Schueneman and Sanchez 1994; Wright et al. 2018). Due to the high $\mathrm{pH}$ buffering capacity of the Histosols in the EAA, the reduction in soil $\mathrm{pH}$ tends to last less than 1 year (Wright et al. 2018).

Minimizing tillage is another recommended practice to prevent increases in soil $\mathrm{pH}$. Tilling for field preparation mixes particles from the lower and upper parts of the soil profile, causing the incorporation of limestone minerals near the soil surface. During this process, $\mathrm{Ca} / \mathrm{Mg}$ minerals from the underlying bedrock are moved upwards, increasing $\mathrm{pH}$ and $\mathrm{P}$ retention near the rooting zone.

\section{IRRIGATION AND WATER MANAGEMENT}

Water management is critical to the mobilization of soil $\mathrm{P}$ and plant uptake. For $\mathrm{P}$ to be transported in the soil and taken up by lettuce, soil moisture is required and may be provided through a proper irrigation program to avoid excess of water in the field, nutrient leaching, or runoff. More detailed information about irrigation management and water requirements of lettuce can be found in EDIS article AE260, Principles and Practices of Irrigation Management for Vegetables, at https://edis.ifas.ufl.edu/publication/ CV107 (Dukes et al. 2021).

In the EAA, fields are overhead-irrigated prior to preparation for lettuce planting during dry periods. Once lettuce germinates, irrigation is provided through the control of water tables via seepage (subirrigation) (Snyder et al. 1978; Bhadha and Schroeder 2017). The recommended water table depths for lettuce grown in the EAA ranges from 18 to 24 inches. Controlling water tables via seepage provides a better management of soil moisture, better control of field drainage, reduction of soil subsidence rates, and reduction of $\mathrm{P}$ leaching and discharge load into waterways in the EAA. In addition, subirrigation avoids the contact of aboveground plant parts with water that might be contaminated with pathogens.

\section{USE OF MICROORGANISMS TO ENHANCE PHOSPHORUS AVAILABILITY}

The low $\mathrm{P}$ mobility and high retention rates in soils worldwide has led agricultural scientists to search for alternative solutions to enhance efficiency of $\mathrm{P}$ in crop production. The use of plant-growth-promoting microorganisms (PGPM) has received increasing attention in recent years. PGPMs are bacterial and fungal species (predominantly the Bacillus, Pseudomonas, Paenibacillus, Penicillium, and Aspergillus genera) capable of improving $\mathrm{P}$ availability through mineralization and solubilization processes. These microbes can release protons, hydroxide ions, enzymes, and organic acids capable of reducing soil $\mathrm{pH}$ near root zones, weakening bonds between $\mathrm{P}$ and soil particles, and converting nonavailable P into available P (Fageria 2009). Microbes called mycorrhizal fungi are capable of colonizing plant roots and building symbiotic relationships with plants. In this case, the fungal hyphae extend farther into the soil and allow more $P$ to be transported to the plant (Fageria 2009). Many PGPM species have been successfully used in agricultural systems in the form of biofertilizers to increase availability of $\mathrm{P}$ and other nutrients in lettuce (Vessey 2003; Kohler et al. 2007).

\section{CULTIVAR SELECTION}

Plants vary in their ability to acquire $P$ from the soil and utilize it efficiently. Plants deploy mechanisms to increase P-use efficiency, including modification of root architecture and density, release of exudates (e.g., enzymes and organic acids that favor $\mathrm{P}$ solubilization in the soil), formation of symbioses with PGPMs, and use or transport of P internally (Fageria 2009). Preliminary studies on lettuce grown on Histosols suggest that specific cultivars may produce acceptable yields under fewer P inputs (G. Kreutz, personal observations).

Phosphorus-efficient cultivars have been developed using breeding approaches for rice, corn, wheat, soybeans, and common beans (van de Wiel et al. 2016; Fageria 2009). 
With the increasing concerns regarding $P$ fertilizers, the concept of improving P-use efficiency in lettuce will likely become more popular among private and public plant breeders worldwide. In lettuce, the mechanisms underlying P-use efficiency remain to be investigated. Phosphorusefficient lettuce could help growers produce with fewer $P$ inputs and decrease crop production costs. Breeding for P-efficient cultivars is a long-term target of the UF/IFAS lettuce breeding program.

\section{WEED CONTROL}

Within the EAA, the subtropical climate conditions are conducive to weed establishment and proliferation, particularly in Histosols. Previous research has found that weeds in the EAA interfere with lettuce primarily through light interception (due to a taller weed canopy) and soil $\mathrm{P}$ absorption, jeopardizing lettuce production (Santos et al. 2004). Furthermore, the application of inappropriate $P$ fertilization rates in lettuce grown in low $\mathrm{P}$ soils of the EAA results in an earlier and more labor-demanding critical period of weed control (Odero and Wright 2013). In extreme situations where weeds are allowed to interfere with lettuce all season-long, yield losses may surpass 70\%, regardless of $\mathrm{P}$ fertilization rates (Figure 3) (Odero and Wright 2013). It is therefore imperative that growers in the EAA follow recommended procedures of weed control and $P$ fertilization in lettuce to minimize nutrient and light competition, weed management costs, and ultimately, yield losses.

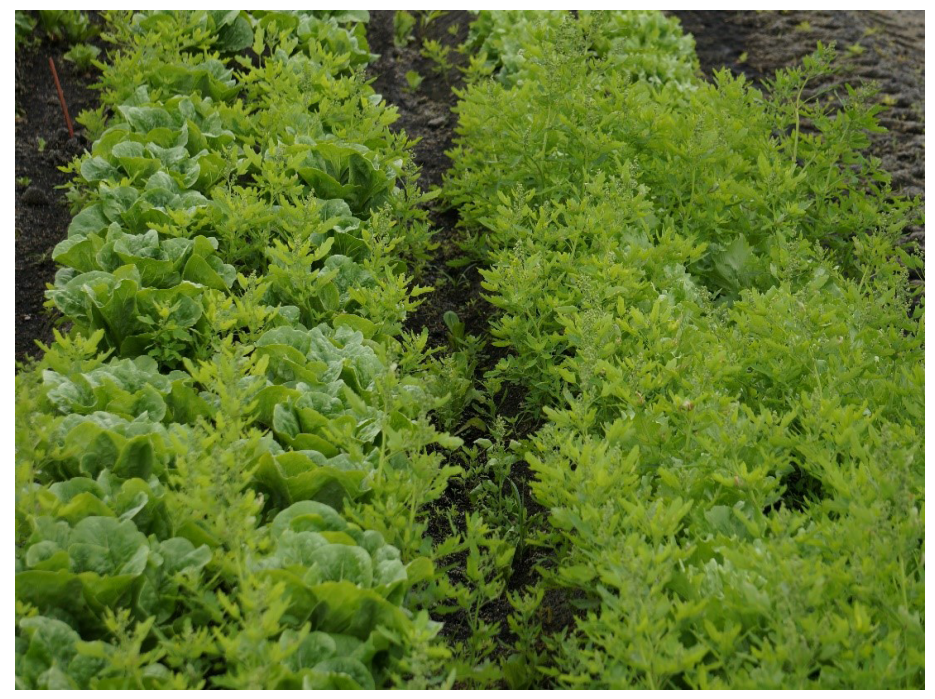

Figure 3. Lettuce field overrun with weeds. The interference of weeds in crop production is an important factor limiting the availability of phosphorus to plants.

Credits: D. Calvin Odero, UF/IFAS

\section{Conclusion}

Phosphorus is a nonrenewable, limited resource. Successful management of $P$ in lettuce fields of the EAA can be achieved through a combination of strategies to increase $P$ utilization efficiency and minimize nutrient losses. These strategies might be simultaneously applicable to local lettuce farmers to reach the objective mentioned above. Special focus should be on testing the soil prior to cultivation; determining appropriate rates, sources, timing, and placement for fertilizer; managing soil $\mathrm{pH}$; maintaining optimum levels of soil moisture; and adequately controlling weed infestations in the fields. Furthermore, utilization of PGPM and the development and adoption of locally adapted P-efficient lettuce cultivars can be alternative strategies for P-use efficiency in the EAA in the future.

\section{Literature Cited}

Bhadha, J. H., and B. L. Schroeder. 2017. "Best Management Practices for Maintaining Water Quality in Sugarcane Cultivation." In Achieving Sustainable Cultivation of Sugarcane Volume 1: Cultivation Techniques, Quality and Sustainability, edited by P. Rott. Cambridge, UK: Burleigh Dodds Science Publishing.

Bhadha, J. H., A. L. Wright, and G. H. Snyder. 2020. "Everglades Agricultural Area Soil Subsidence and Sustainability." EDIS 2020 (2). https://doi.org/10.32473/ edis-ss523-2020

Bottcher, A. B., F. T. Izuno, and E. D. Hanlon. 1997. Procedural Guide for the Development of Farm-Level Best Management Practice Plans for Phosphorus Control in the Everglades Agricultural Area. Circular 1177. Gainesville: University of Florida Institute of Food and Agricultural Sciences. https://www.sfwmd.gov/sites/default/files/documents/wq14100.pdf

Daroub, S. H., T. A. Lang, O. A. Diaz, and M. Chen. 2018. "Best Management Practices in the Everglades Agricultural Area: Soil Testing." EDIS 2005 (7). https://doi.org/10.32473/ edis-ss445-2005

Dukes, M. D., L. Zotarelli, G. D. Liu, and E. H. Simonne. 2021. "Principles and Practices of Irrigation Management for Vegetables.” EDIS 2006 (3). https://edis.ifas.ufl.edu/ cv107

Fageria, N. K. 2009. The Use of Nutrients in Crop Plants. Boca Raton: CRC Press. 
Guzman, V. L., C. A. Sanchez, and R. E. Lucas. 1987. "Banding Fertilizers for Improved Fertilizer Use Efficiency for Lettuce on Everglades Histosols." Proceeding of the Florida State Horticultural Society 100:200-203. https://journals. flvc.org/fshs/article/view/94553/90580

Hochmuth, G., and E. Hanlon. 2019. "Principles of Sound Fertilizer Recommendations.” EDIS 2010 (2). https://edis. ifas.ufl.edu/ss527

Hochmuth, G., E. Hanlon, R. Nagata, G. Snyder, and T. Schueneman. 2018. "Fertilization Recommendations for Crisphead Lettuce Grown on Organic Soils in Florida." EDIS 2018 (6). https://edis.ifas.ufl.edu/wq114

Kohler, J., F. Caravaca, L. Carrasco, and A. Roldán. 2007. "Interactions between a Plant Growth-Promoting Rhizobacterium, an AM Fungus and a Phosphate-Solubilising Fungus in the Rhizosphere of Lactuca sativa." Applied Soil Ecology 35 (3): 480-487. https://doi.org/10.1016/j. apsoil.2006.10.006

Li, B., I. Boiarkina, B. Young, W. Yu, and N. Singhal. 2018. "Prediction of Future Phosphate Rock: A Demand Based Model." Journal of Environmental Informatics 31 (1): 41-53. https://doi.org/10.3808/jei.201700364

Mylavarapu, R., G. Hochmuth, V. Nair, A. Wright, J. McCray, and Y. C. Li. 2018. "Calibration of Soil Test Interpretations and Nutrient Recommendations for Major Commodities Grown across Florida as Best Management Practice for Sustainable Agriculture." Final Project Report, Grant Contract \# 024018, Florida Department of Agriculture and Consumer Services and University of Florida.

Mylavarapu, R., Y. Li, M. Silveira, C. Mackowiak, and M. McCray. 2021. "Soil-Test-Based Phosphorus Recommendations for Commercial Agricultural Production in Florida." EDIS 2021 (1). https://doi.org/10.32473/edis-ss699-2021

Odero, D., and A. L. Wright. 2013. "Phosphorus Application Influences the Critical Period of Weed Control in Lettuce." Weed Science 61 (3): 410-414. https://doi. org/10.1614/WS-D-12-00107.1

Sanchez, C. A., S. Swanson, and P. S. Porter. 1990. "Banding P to Improve Fertilizer Use Efficiency of Lettuce." Journal of the American Society for Horticultural Science 115 (4): 581-584. https://doi.org/10.21273/JASHS.115.4.581
Sandoya, G., and H. Lu. 2020. "Evaluation of Lettuce Cultivars for Production on Muck Soils in Southern Florida." EDIS 2020 (1). https://doi.org/10.32473/edis-hs1225-2020

Santos, B. M., J. A. Dusky, T. A. Bewick, and D. G. Shilling. 2004. "Mechanisms of Interference of Smooth Pigweed (Amaranthus hybridus) and Common Purslane (Portulaca oleracea) on Lettuce as Influenced by Phosphorus Fertility." Weed Science 52 (1): 78-82. https://doi.org/10.1614/ P2002-171

Schueneman, T. J., and C. A. Sanchez. 1994. "Vegetable Production in the EAA." In Everglades Agricultural Area: Water, Soil, Crop, and Environmental Management, edited by A. B. Bottcher and F. T. Izuno, 238-277. Gainesville: University Press of Florida.

Snyder, G. H., H. W. Burdine, J. R. Crockett, G. J. Gascho, D. S. Harrison, G. Kidder, J. W. Milshoe, D. L. Myhre, F. M. Pate, and S. F. Shih. 1978. "Water Table Management for Organic Soil Conservation and Crop Production in the Florida Everglades." Gainesville, FL: University of Florida Agricultural Experiment Station Bull. 801.13-14.

Van de Wiel, C. C. M., C. G. van der Linden, and O. E. Scholten. 2016. "Improving Phosphorus Use Efficiency in Agriculture: Opportunities for Breeding." Euphytica 207:1-22. https://doi.org/10.1007/s10681-015-1572-3

Vessey, J. K. 2003. "Plant Growth Promoting Rhizobacteria as Biofertilizers." Plant and Soil 255:571-586. https://doi. org/10.1023/A:1026037216893

Wright, A. L., E. A. Hanlon, and R. W. Rice. 2018. "Managing $\mathrm{pH}$ in the Everglades Agricultural Soils." EDIS 2012 (4). https://edis.ifas.ufl.edu/ss500 
Table 1. Interpretation of water-extractable $\mathrm{P}(\mathrm{Pw})$ soil test and recommendation of $\mathrm{P}$ fertilizer rates for iceberg and romaine lettuce produced in the Histosols of the EAA.

\begin{tabular}{|c|c|c|c|c|c|c|c|c|}
\hline \multicolumn{9}{|c|}{ Phosphorus (Water-extractable $\mathbf{P}$ index) ${ }^{1}$} \\
\hline 3 & 6 & 9 & 12 & 15 & 18 & 21 & 24 & $\geq 27$ \\
\hline \multicolumn{9}{|c|}{ Phosphorus fertilizer recommendation ( $\mathrm{lb} \mathrm{P}_{2} \mathrm{O}_{5}$ banded per acre) ${ }^{2}$} \\
\hline 200 & 175 & 150 & 125 & 100 & 75 & 50 & 25 & 0 \\
\hline
\end{tabular}

